\title{
Prinsip Perencanaan dan Kriteria Pengendalian Pengembangan Fasilitas Rest-Area pada Jalan Tol di Indonesia
}

\author{
Planning Principles and Development Control Criteria of Rest Area Facilities \\ on Toll Roads in Indonesia
}

\author{
Gede Windu Laskara ${ }^{1^{*}}$ \\ ${ }^{1}$ Program Studi Arsitektur, Fakultas Teknik, Universitas Udayana, Jalan Kampus Bukit Jimbaran, Kecamatan \\ Kuta Selatan, Kabupaten Badung, Provinsi Bali, 80361, Indonesia; \\ *Penulis korespondensi.e-mail: windulaskara@unud.ac.id \\ (Diterima: 15 Februari 2021; Disetujui: 24 April 2021)
}

\begin{abstract}
Stopovers and relaxing facilities are important in intercity travel on toll roads. Long distances travel times in toll roads increase the supply and demand of these facilities in Indonesia. Not only the needs for refueling and resting, but also new support facilities demanded in rest area are often found, such as shopping, restaurant, worship place, and others. This phenomenon has attracted many investors to establish rest area with those complex facilities in term of business profit. To prevent negative impact of development and to protect main function of toll roads, this paper will discuss the planning and development control principles of rest areas located on toll roads in Indonesia. Analysis of components and criteria for rest areas on toll roads are generated by analyzing problems occurred. Site location, site area, accessibility, and main facilities specification are absolute factors, while zoning, circulation, road signage, and site utilities are conditional factors. The planning principles is to guarantee safety, security, and convenience of all activities in and around rest area and toll road. This research describes several criteria and components that should be controlled in order to achieve rest area planning principles that determined by qualitative methods.
\end{abstract}

Keywords: convenience, planning, rest area, safety, security, toll roads

\section{ABSTRAK}

Tempat persinggahan dan fasilitas relaksasi merupakan hal penting dalam perjalanan antar kota pada jalan tol. Jarak dan waktu tempuh yang panjang di jalan tol semakin meningkatkan angka supply dan demand fasilitas persinggahan di Indonesia. Tidak hanya fasilitas pengisian bahan bakar dan beristirahat, fungsi yang sering ditemukan antara lain pusat perbelanjaan, restoran, tempat peribadatan, dan lainnya. Fenomena ini menarik banyak investor untuk mendirikan fasilitas rest-area dengan fasilitas pelengkap yang kompleks dengan tujuan keuntungan bisnis. Untuk mencegah dampak negatif pembangunan dan untuk melindungi fungsi utama jalan tol, kajian ini mengkaji prinsip perencanaan dan komponen pengendalian pembangunan rest-area yang terletak pada jalan tol di Indonesia. Analisis dihasilkan dengan mengklasifikasi persoalan dan gangguan yang terjadi di lapangan. Dirumuskan bahwa, lokasi tapak, luas lahan, aksesibilitas, dan luas fasilitas utama adalah komponen mutlak, sedangkan zonasi, sirkulasi, penanda, dan utilitas merupakan komponen bersyarat. Prinsip perencanaannya untuk menjamin keselamatan, keamanan, dan kenyamanan pelanggan dan pengendara di sekitar rest-area. Kajian ini menjelaskan beberapa kriteria dan 
komponen yang harus dikelola untuk mencapai prinsip-prinsip perencanaan rest-area yang ditentukan melalui metode kualitatif.

Kata kunci: jalan tol, keamanan, kenyamanan, keselamatan, perencanaan, rest-area

\section{PENDAHULUAN}

Keberadaan rest-area sebagai fasilitas pelengkap fungsi jalan tol memiliki peran dalam meminimalisir peluang kecelakaan lalu lintas di jalan tol. Rest-area penting dalam memberikan kesempatan beristirahat, letaknya berada di luar area pembatas jalan yang dilengkapi dengan prasarana penunjang bagi pengendara dan kendaraan (Hartopo, 2006). Meningkatnya pengguna jalan tol menuntut meningkatnya pelayanan pendukung, rest-area tidak hanya sekedar pengisian bahan bakar dan komersial namun fasilitas relaksasi akibat kelelahan (Arini \& Dwiyanti, 2017; Magfirona et al., 2018)

Pengembangan bisnis pada rest-area berangkat dari aturan investasi jalan tol yang mewajibkan menyediakan area relaksasi sejenak sebagai bagian dari tujuan keselamatan dalam operasi jalan. Data lalu lintas tahun 2019 (Marga, 2019) rata-rata volume kendaraan yang melintas sebanyak 67,345 kendaraan, dengan rekor volume lalu lintas tertinggi jalan tol di Indonesia sebanyak 166,574 kendaraan pada 9 Juni 2019 di Tol Jakarta-Cikampek. Rata-rata jumlah kendaraan yang melalui jalan tol per tahun yaitu 880,057,037 kendaraan, dan tahun 2014 mencapai 1.3 milyar kendaraan (Marga, 2015).

Terdapat kemungkinan meningkatnya jumlah pengendara sebanyak 3\% setiap tahunnya (Marga, 2015), namun ironisnya jumlah kecelakaan di jalan tol turut juga mengalami peningkatan.

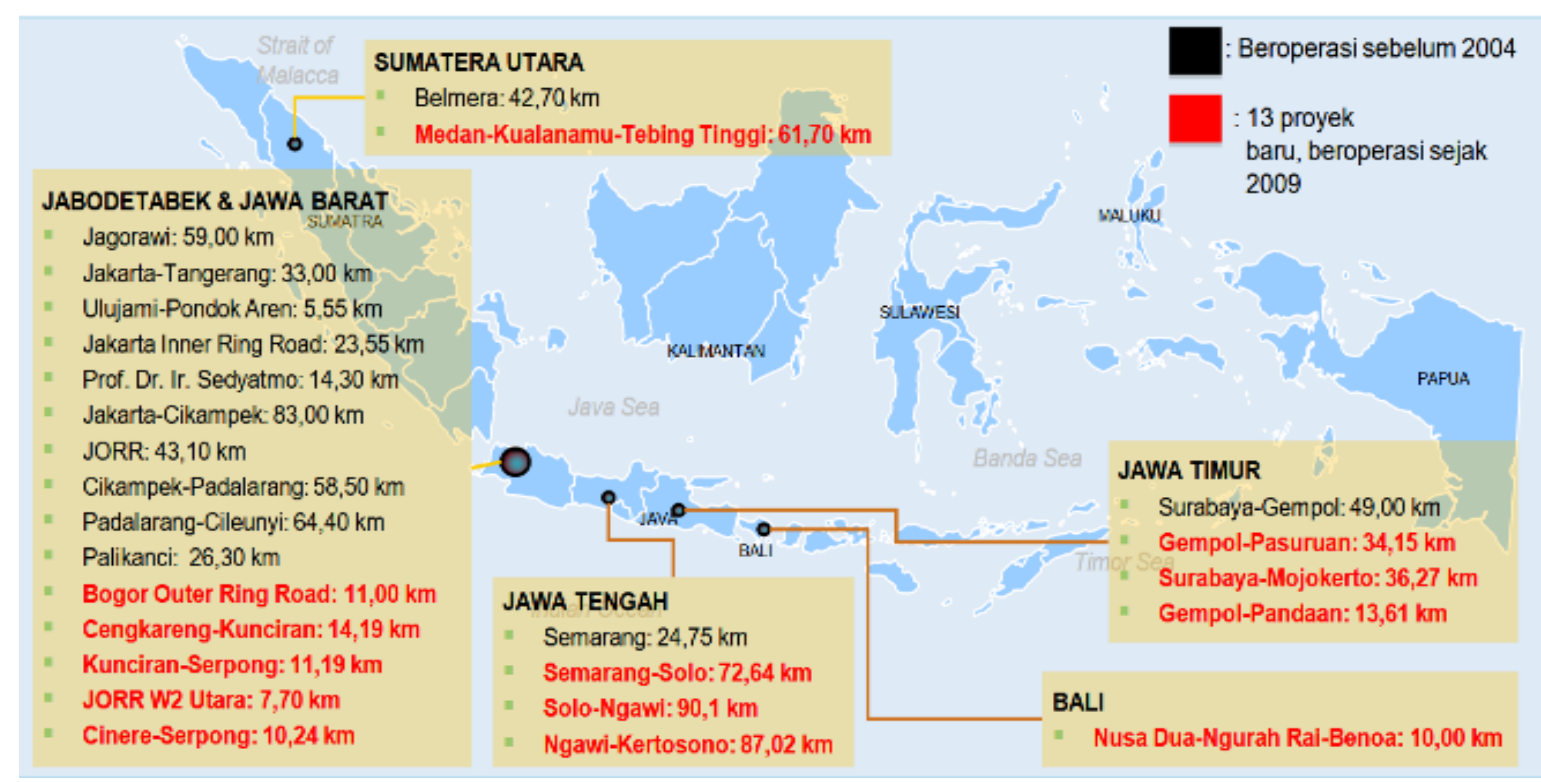

Gambar 1. Jalan tol di bawah PT. Jasa Marga Sumber: PT. Jasa Marga, 2015.

Pada tahun 2017 terjadi sebanyak 1,075 kecelakaan, dan 2018 sebanyak 1,135 kecelakaan. Teridentifikasi $80 \%$ hingga $90 \%$ kecelakaan disebabkan oleh faktor manusia (kelelahan), infrastruktur berkisar 10\% hingga $20 \%$, dan faktor kendaraan kurang dari $10 \%$ (Perhubungan, 2019). Fenomena tersebut dapat diantisipasi dengan menyiapkan fasilitas rest- area yang berfungsi optimal dan dapat memenuhi kebutuhan pengendara. Fasilitas restarea wajib memenuhi prinsip dan kriteria perencanaan yang bertujuan menciptakan area publik kompak sebagai fungsi penunjang jalan tol, fungsi campuran peristirahatan, komersial, dan perawatan kendaraan yang menjamin kualitas visual kawasan serta berdampak 
ekonomi lokal / UMK (Al-Kaisy et al., 2012; Laskara, 2016; Kementerian PUPR, 2018).

Hasil kajian pada 27 ruas jalan tol di Indonesia ditemukan 2 substansi yang selalu tidak dapat dipenuhi dalam Standar Pelayanan Minimal (SPM) jalan tol, yaitu 1) kondisi fisik jalan tol; dan 2) kondisi pelayanan keselamatan, yaitu penyediaan fasilitas pendukung keselamatan pengendara yang belum memenuhi SPM (Makmur \& Rajagukguk, 2015). Fasilitas penunjang keselamatan berupa fasilitas peristirahatan rest-area yang sesuai standar menjadi penting. Menteri PUPR, Basuki Hadimuljono, menyatakan akan melakukan evaluasi terhadap perencanaan dan desain restarea, karena sering ditemukan kemacetan di sekitarnya akibat perencanaan yang tidak tepat, contohnya lokasi dan luas area parkir. Selain itu, sering terjadi kecelakaan yang disebabkan kurang tepatnya penataan fungsi pendukung rest-area yang terlalu dekat dengan bibir jalan tol (CNN Indonesia, 2019).

Hal tersebut membuktikan apabila tidak diatur perencanaannya, rest-area tidak hanya menimbulkan masalah tata ruang, tetapi juga dapat menimbulkan konflik kepentingan pelanggan dengan pengguna jalan tol. Tujuan penelitian ini adalah untuk merumuskan prinsip perencanaan, komponen dan kriteria pengendalian rest-area pada jalan tol di Indonesia.

\section{METODOLOGI}

Penelitian ini dilakukan dengan metode kualitatif dengan teknik analisis evaluatif (Patton, 1987; Pickett et al., 2013; Moughtin, 2007; Dumbaugh \& Gattis, 2005; Cuesta et al., 2003). Melakukan evaluasi dan analisis empiris pada persoalan-persoalan yang terjadi pada restarea. Metode pengumpulan data adalah survey primer dan sekunder.

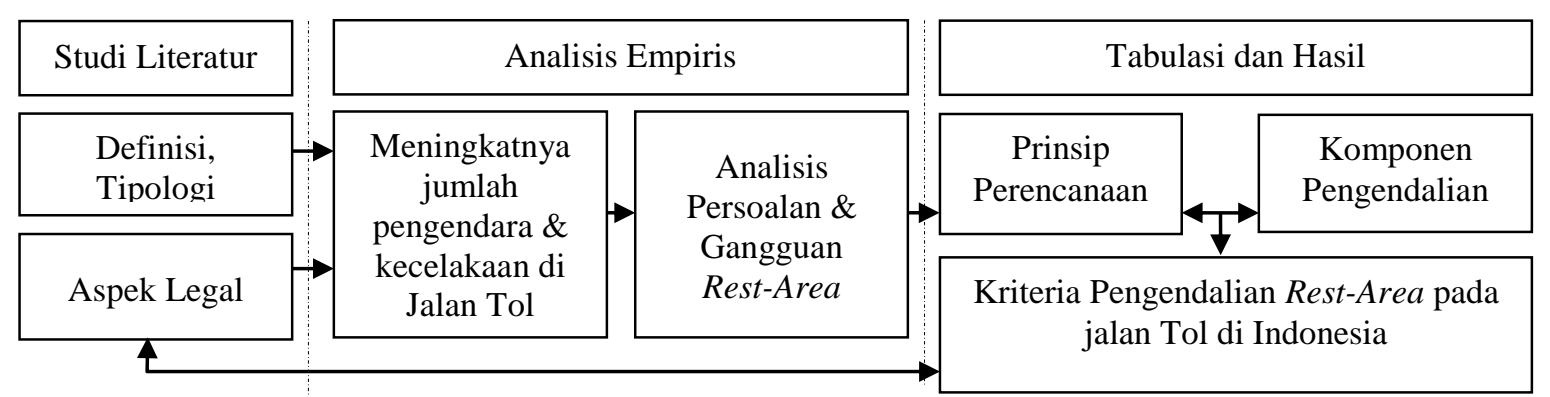

Gambar 2. Tahapan penelitian

Survey primer dilakukan dengan observasi lapangan pada rest-area 97 di tol Cipularang, sebagai salah satu rest-area terpadat yang berada pada area kilometer yang memiliki tingkat kecelakaan yang relatif tinggi. Tercatat sejak tahun 2012 hingga 2017 telah terjadi 87 kejadian dengan 106 korban jiwa pada kilometer 90 hingga 99 pada tol Cipularang (Hanafi et al., 2019). Data sekunder dikumpulkan dari beberapa hasil kajian dan regulasi institusional terkait. Tahapan penelitian seperti gambar 2.

\section{HASIL DAN PEMBAHASAN}

Demi meningkatkan layanan rest-area dan kenyamanan pengendara pada jalan bebas hambatan, jumlah rest-area terus bertambah. Dengan kondisi ini perencanaannya harus memperhatikan dampak yang akan disebabkan terhadap lingkungan disekitar, tidak hanya keselamatan namun juga tampilan visual koridor jalan serta kualitas fisik kawasannya (Moughtin, 2007; Arvidsson, 2007; Harvey \& Aultman-Hall 2015; Laskara et al., 2020).

Sejarahnya, rest-area dibangun untuk alasan keamanan sebagai tempat pemberhentian darurat atau sementara bagi pengendara kendaraan bermotor. Pada tahun 1958, karena banyaknya pengendara yang beristirahat di pinggir jalan tol dan taman di sekitar jalan tol maka disusunlah standar perencanaan fasilitas rest-area. Sejak saat itu tumbuh 1,200 rest-area 
dalam 22 tahun (A Policy on Safety Rest-areas for the National System of Interstate and Defense Highways, 1958).

Secara internasional, terdapat 5 (lima) tipe rest-area, yaitu tipe $\mathrm{A}$, tipe $\mathrm{B}$, tipe $\mathrm{C}$, tipe D, dan tipe D1 (Autoceste, 2012). Di Indonesia, berdasarkan Peraturan Menteri PUPR Nomor 10/PRT/M/2018 tentang Tempat Istirahat dan Pelayanan (TIP) pada jalan tol disebutkan 3 tipe rest-area, yaitu tipe $\mathrm{A}$, tipe $\mathrm{B}$, dan tipe $\mathrm{C}$. Tipe C tidak dimasukkan sebagai objek studi penelitian ini, karena dinyatakan pada pasal 5 ayat 5 , rest-area tipe $\mathrm{C}$ hanya bersifat darurat dan sewaktu-waktu yaitu beroperasi hanya pada masa libur panjang Lebaran atau Natal. Standar TIP berdasarkan Peraturan Menteri PUPR pada tabel 1.

Pada pasal 7 Peraturan Pemerintah Nomor 7/2005 dinyatakan jalan tol tidak digunakan untuk keperluan menaikkan atau menurunkan penumpang, barang, atau hewan karena dapat membahayakan penumpang serta menyebabkan kemacetan, maka dibutuhkan fungsi naik dan turun penumpang berupa tempat peristirahatan. Berdasarkan Peraturan Menteri PUPR Nomor 10/PRT/M/2018 disebutkan bahwa pada jalan tol wajib menyediakan tempat istirahat dan pelayanan, disediakan paling sedikit satu untuk setiap jarak 50 kilometer.

Jalan tol harus menyediakan sarana komunikasi, sarana deteksi pengamanan lain yang memungkinkan pertolongan dapat segera sampai, serta upaya pengamanan terhadap pelanggaran, kecelakaan, dan gangguan keamanan lainnya (Ogden \& Bennet, 1984). Dalam Keputusan Kepala Badan Pengatur Jalan Tol Nomor 16/KPTS/ BPJT/2008 tentang Master Plan Tempat Peristirahatan Dan Pelayanan pada Jalan Tol, bahwa lahan di ruang milik jalan tol di luar ruang manfaat jalan tol, dapat dipergunakan sebagai tempat istirahat dan pelayanan tol, sepanjang masih merupakan sarana penunjang dalam pengusahaan jalan tol dan memenuhi ketentuan teknik jalan tol.

Standar perencanaan yang menyangkut penentuan lokasi rest-area antara lain panjang jalan minimum, lokasi dan jarak kota terdekat, volume jalan, tingkat kecelakaan, dan kondisi geografis / struktur tanah. Ketentuan teknik, berupa kriteria dengan analisis dan asumsi terhadap tingkat kelelahan pengguna jalan untuk menentukan lokasi dan posisi yang ideal bagi pengadaan fasilitas rest-area pada jalan tol. (Marga, 1999; Karsaman, 2010; Pérez-Acebo \& Romo-Martín, 2019).

Tabel 1. Standar perencanaan Tempat Istirahat dan Pelayanan (TIP) pada jalan tol di Indonesia

\begin{tabular}{|c|c|c|c|c|c|c|}
\hline Tipe & Fungsi Utama & $\begin{array}{l}\text { Interval } \\
\text { min. }\end{array}$ & $\begin{array}{l}\text { Lahan } \\
\text { min. }\end{array}$ & Parkir min. & $\begin{array}{l}\text { Toilet } \\
\text { min. }\end{array}$ & $\begin{array}{c}\text { Standar Luas } \\
\text { min. }\end{array}$ \\
\hline A & $\begin{array}{l}\text { ATM; Toilet; } \\
\text { Klinik Kesehatan; } \\
\text { Bengkel; Warung/ } \\
\text { Kios; Minimarket; } \\
\text { Mushola; SPBU; } \\
\text { Restoran; RTH; } \\
\text { Area Parkir; } \\
\text { Penginapan (Opsi) }\end{array}$ & $\begin{array}{l}\text { Minimal } \\
1 @ 50 \text { km }\end{array}$ & $\begin{array}{l}6 \mathrm{Ha} / \\
60,000 \mathrm{~m}^{2} \\
\text { Lebar } \\
>150 \mathrm{~m}\end{array}$ & $\begin{array}{l}\text { Gol. I } \\
2,500 \mathrm{~m}^{2} \\
100 \text { unit } \\
\text { Gol II s/d. V } \\
3,000 \mathrm{~m} 2 \\
50 \text { unit }\end{array}$ & $\begin{array}{l}10(\mathrm{P}) \\
20(\mathrm{~W}) \\
>30 \mathrm{~m}^{2}\end{array}$ & $\begin{array}{l}\text { SPBU } 500 \mathrm{~m}^{2} \\
\text { Bengkel } 80 \mathrm{~m}^{2} \\
\text { Klinik } 50 \mathrm{~m}^{2} \\
\text { Mushola } 400 \mathrm{~m}^{2} \\
\text { Bengkel } 500 \mathrm{~m}^{2} \\
\text { Restoran } 1,000 \\
\mathrm{~m}^{2} \\
\text { Kios } 300 \mathrm{~m}^{2}\end{array}$ \\
\hline B & $\begin{array}{l}\text { ATM; Toilet; } \\
\text { Warung/Kios; } \\
\text { Minimarket;Mushola } \\
\text { Restoran; RTH; } \\
\text { Area Parkir }\end{array}$ & $\begin{array}{l}\text { Minimal } \\
1 @ 30 \mathrm{~km} \\
>10 \mathrm{~km} \\
\text { antar Tipe B }\end{array}$ & $\begin{array}{l}3 \mathrm{Ha} / \\
30,000 \mathrm{~m}^{2} \\
\text { Lebar } \\
>100 \mathrm{~m}\end{array}$ & $\begin{array}{l}\text { Gol. I } \\
800 \mathrm{~m}^{2} \\
30 \text { unit } \\
\text { Gol II s/d. V } \\
1,200 \mathrm{~m} 2 \\
20 \text { unit } \\
\end{array}$ & $\begin{array}{l}4(\mathrm{P}) \\
10(\mathrm{~W}) \\
>14 \mathrm{~m}^{2}\end{array}$ & $\begin{array}{l}\text { Mushola } 200 \mathrm{~m}^{2} \\
\text { Bengkel } 80 \mathrm{~m}^{2} \\
\text { Restoran } 800 \mathrm{~m}^{2} \\
\text { Kios } 200 \mathrm{~m}^{2}\end{array}$ \\
\hline Geom & tri Lokasi/Lahan & $\begin{array}{l}\text { Daerah relati } \\
\text { Kemiringan } \\
\text { Landai maks }\end{array}$ & atar dan I & ; $1.5 \mathrm{~km}$ sete & /sebelu & rsimpangan jalan \\
\hline
\end{tabular}

Sumber: Peraturan Menteri PUPR Nomor 10/PRT/M/2018 tentang TIP pada Jalan Tol (2018) 
Berdasarkan hasil studi empiris, pada tabel 2, ada dua jenis potensi dampak negatif yang bisa terjadi jika pembangunan rest-area tidak dikendalikan. Pertama, dampak negatif jika tidak ada rest-area dapat mengancam keselamatan pengendara, akibat kelelahan berkendara yang terlalu lama tanpa beristirahat. Pengendara tidak punya kesempatan untuk relaksasi, maka rest-area dapat juga digunakan sebagai tempat rekreasi/piknik, tidak jarang rest-area memiliki panorama yang indah, seperti pada tol Cipularang (Elfiansyah, 2007; Al-Kaisy et al., 2012). Kedua, dampak negatif jika terlalu banyak rest-area dapat 1) mengancam keselamatan pengendara, akibat banyak gangguan samping pada jalur keluar masuk rest-area yang merupakan daerah rawan kecelakaan; 2) memperlambat laju kendaraan di jalan tol akibat gangguan lalu lintas sehingga kenyamanan dan kelancaran lalu lintas berkurang. Selain itu, jika terlalu banyak, restarea berdampak pada 3) operasional tidak efisien, merugikan secara ekonomi dan bisnis (jumlah permintaan dan pasokan tidak seimbang); 4) gangguan visual pada jalan tol akibat banyaknya jumlah penanda / rambu di tepi jalan tol di sekitar rest-area (Russel, 1986; Moughtin, 2007; Pratama, 2014).

Tabel 2. Analisis potensi persoalan, gangguan, dampak gangguan dan komponen pengendalian Rest-Area

\begin{tabular}{|c|c|c|c|}
\hline $\begin{array}{l}\mathbf{N} \\
\mathbf{0}\end{array}$ & Potensi Persoalan dan Gangguan & $\begin{array}{l}\text { Dampak } \\
\text { Gangguan }\end{array}$ & $\begin{array}{l}\text { Komponen } \\
\text { Pengendalian }\end{array}$ \\
\hline 1 & $\begin{array}{l}\text { Pintu masuk / keluar tidak direncanakan dengan baik } \\
\text { menimbulkan gangguan samping di jalan tol, menyebabkan } \\
\text { kemacetan lalu lintas, berpotensi kecelakaan. }\end{array}$ & $\begin{array}{l}\text { Kenyamanan } \\
\text { Keselamatan }\end{array}$ & $\begin{array}{l}\text { Zonasi Tapak; } \\
\text { Aksesibilitas }\end{array}$ \\
\hline 2 & $\begin{array}{l}\text { Interval antara rest-area yang terlalu dekat dan terlalu dekat } \\
\text { kota, beberapa rest-area akan sepi pelanggan. Hal ini dapat } \\
\text { menyebabkan meningkatnya gangguan samping di jalan tol. }\end{array}$ & $\begin{array}{l}\text { Keselamatan } \\
\text { Kenyamanan }\end{array}$ & $\begin{array}{l}\text { Lokasi Tapak } \\
\text { (Interval) }\end{array}$ \\
\hline 3 & $\begin{array}{l}\text { Interval antara rest-area yang terlalu jauh, dapat menyebabkan } \\
\text { pengemudi kelelahan tanpa istirahat. }\end{array}$ & Keselamatan & $\begin{array}{c}\text { Lokasi Tapak } \\
\text { (Interval) }\end{array}$ \\
\hline 4 & $\begin{array}{l}\text { Bangunan dan aktivitas pengunjung rest-area yang terlalu dekat } \\
\text { dengan jalan tol berbahaya bagi pengunjung dan pengemudi tol. }\end{array}$ & Keselamatan & $\begin{array}{l}\text { Luas Tapak; } \\
\text { Zonasi Tapak }\end{array}$ \\
\hline 5 & $\begin{array}{l}\text { Kebutuhan utama rest-area tidak proporsional, didominasi } \\
\text { fungsi komersial, termasuk penyediaan sarana dan prasarana } \\
\text { pendukungnya. Contoh, luas lot parkir dan mushola di bawah } \\
\text { standar dampaknya jumlah antrian menumpuk. }\end{array}$ & Kenyamanan & $\begin{array}{l}\text { Luas Tapak; } \\
\text { Luas Fasilitas }\end{array}$ \\
\hline 6 & $\begin{array}{l}\text { Sistem sirkulasi dan aksesibilitas fungsi utama kurang optimal, } \\
\text { mengganggu kelancaran dalam rest-area, terutama bagi yang } \\
\text { berkepentingan pengisian bahan bakar saja. Sirkulasi pejalan } \\
\text { kaki dan penyandang cacat kurang diperhatikan/minim fasilitas. }\end{array}$ & Kenyamanan & $\begin{array}{l}\text { Aksesibilitas } \\
\text { Sirkulasi }\end{array}$ \\
\hline 7 & $\begin{array}{l}\text { Belum terpenuhinya kebutuhan jumlah lot parkir yang } \\
\text { mengakibatkan antrian kendaraan hingga keluar dari lahan rest- } \\
\text { area dan berada pada jalan tol. }\end{array}$ & $\begin{array}{l}\text { Kenyamanan } \\
\text { Keselamatan }\end{array}$ & $\begin{array}{l}\text { Luas Tapak; } \\
\text { Luas Fasilitas } \\
\text { Sirkulasi } \\
\end{array}$ \\
\hline 8 & $\begin{array}{l}\text { Luas rest-area tidak sesuai dengan jumlah dan jenis fasilitas } \\
\text { yang disediakan, sehingga terjadi overcrowd atau terlalu sepi. } \\
\text { Hal ini dapat mendorong terjadinya kriminalitas }\end{array}$ & $\begin{array}{l}\text { Kenyamanan } \\
\text { Keamanan }\end{array}$ & $\begin{array}{l}\text { Luas Tapak; } \\
\text { Luas Fasilitas }\end{array}$ \\
\hline 9 & $\begin{array}{l}\text { Penataan dan pengelompokan (zonasi) aktivitas di dalam rest- } \\
\text { area kurang baik yang menimbulkan konflik kegiatan. } \\
\text { Misalnya zona bersantap dan beristirahat berdekatan dengan } \\
\text { zona perawatan kendaraan, mengurangi kenyamanan dan } \\
\text { berbahaya bagi pelanggan akibat dampak polusi/limbah. }\end{array}$ & $\begin{array}{l}\text { Keselamatan } \\
\text { Kenyamanan }\end{array}$ & Zonasi Tapak \\
\hline 10 & $\begin{array}{l}\text { Penanda (signage) rest-area tidak berfungsi optimal. Misalnya } \\
\text { penanda gerbang terlalu dekat karena kendaraan melaju dengan } \\
\text { cepat, rest-area sering terlewati. Hal ini berpotensi kecelakaan } \\
\text { akibat rem mendadak. }\end{array}$ & $\begin{array}{l}\text { Kenyamanan } \\
\text { Keselamatan }\end{array}$ & $\begin{array}{l}\text { Penanda/ } \\
\text { Rambu } \\
\text { (Signage) }\end{array}$ \\
\hline 11 & $\begin{array}{l}\text { Lokasi rest-area terletak pada tanjakan / turunan / tikungan tol, } \\
\text { sehingga berbahaya saat melakukan manuver keluar-masuk }\end{array}$ & $\begin{array}{l}\text { Keselamatan } \\
\text { Kenyamanan }\end{array}$ & $\begin{array}{l}\text { Aksesibilitas } \\
\text { Lokasi Tapak }\end{array}$ \\
\hline
\end{tabular}




\begin{tabular}{llcc}
\hline $\mathbf{N}$ & Potensi Persoalan dan Gangguan & $\begin{array}{c}\text { Dampak } \\
\text { Gangguan }\end{array}$ & $\begin{array}{c}\text { Komponen } \\
\text { Pengendalian }\end{array}$ \\
\hline 12 & $\begin{array}{l}\text { Pencahayaan di dalam rest-area kurang baik, remang-remang, } \\
\text { menimbulkan rasa takut dan peluang kriminalitas }\end{array}$ & $\begin{array}{c}\text { Keamanan } \\
\text { Kenyamanan }\end{array}$ & Utilitas \\
\hline
\end{tabular}

Hasil audit keselamatan pelayanan jalan tol di Indonesia disimpulkan terdapat 5 indikator pelayanan keselamatan atau $29 \%$ dari standar pelayanan minimal pada jalan tol di Indonesia yang selalu tidak dapat dipenuhi yaitu penanda/rambu, marka jalan, guide post, reflector, pagar rumija (guard rail), dan penerangan jalan umum. (Karsaman, 2010; Makmur \& Rajagukguk, 2015). Daya tarik restarea berkorelasi tinggi dengan ragam aktivitas, wujud fisik dan lingkungannya (Purboyo \& Santoso, 2016).

Prinsip normatif pengendaliannya yaitu menekan efek negatif pengembangan rest-area. Prinsip perencanaannya dirumuskan melalui hasil klasifikasi dampak gangguan yang disebabkan oleh persoalan yang terjadi di lapangan. Komponen pengendalian adalah komponen yang harus diatur dalam perencanaan rest-area, komponen ini dihasilkan dari kajian dan klasifikasi aspek-aspek yang menyebabkan terjadinya gangguan di lapangan. Uraian persoalan, gangguan dan komponen lihat pada Tabel 2.

Prinsip perencanaan rest-area dirumuskan melalui hasil analisis dampak gangguan, yaitu memastikan seluruh proses perencanaan dapat meminimalisir bahkan meniadakan dampak gangguan yang akan terjadi. Maka, dari hasil klasifikasi pada Tabel 2 diketahui prinsip perencanaan fasilitas rest-area pada jalan tol di Indonesia adalah untuk menjamin 1) keselamatan (safety); 2) keamanan (security); dan 3) kenyamanan (convenience).

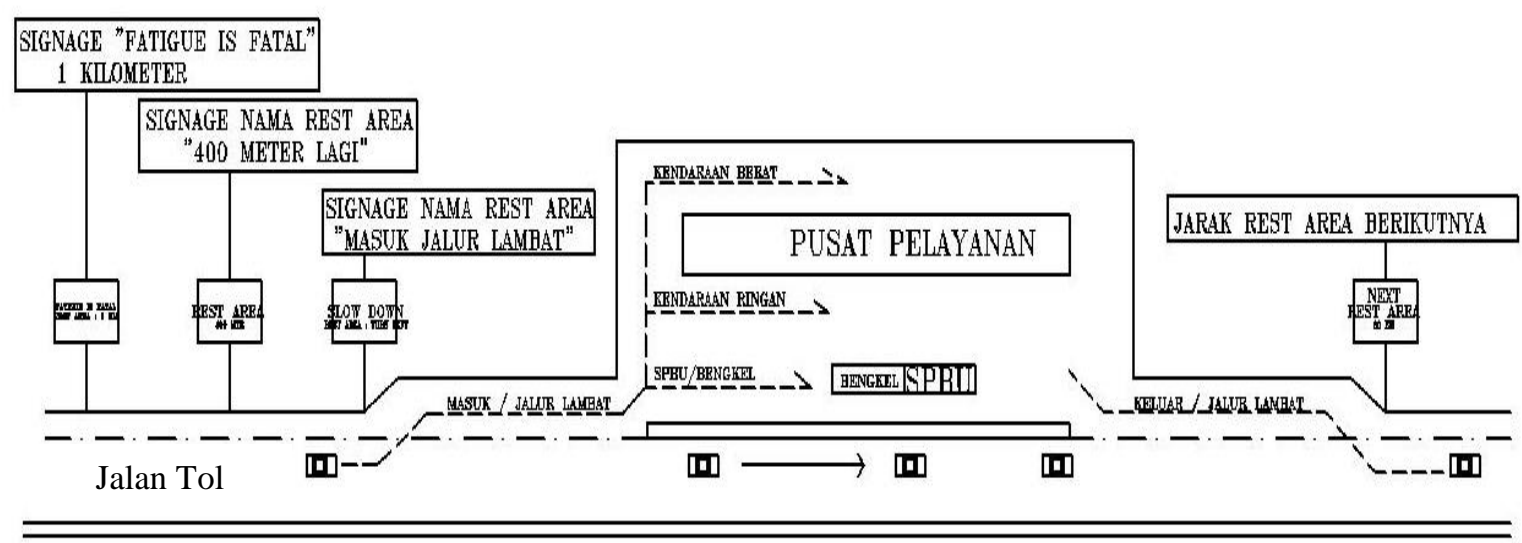

Jalan Tol
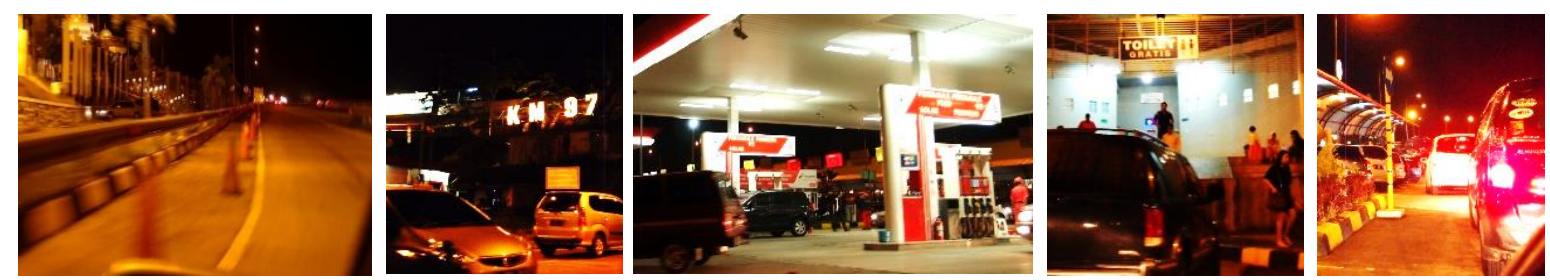

Gambar 3. Atas : Ilustrasi Penataan Rest-Area. Bawah : Kondisi Rest-Area Nomor 97 di Jalan Tol Cipularang 
Menjamin keselamatan (safety) bagi pelanggan dan pengguna jalan tol di sekitar restarea dari bahaya kecelakaan lalu lintas. Keamanan (security) mencakup upaya preventif dan antisipatif melalui upaya perencanaan dalam meminimalisir tindakan kriminalitas di/ dan sekitar lingkungan rest-area. Kenyamanan (convenience) mencakup segala bentuk upaya untuk menjamin optimasi, efisiensi, dan kelayakan pelayanan bagi pelanggan rest-area.

Pada dasarnya komponen yang akan dikendalikan (scope of issue) dirumuskan dari persoalan yang ditemukan di lapangan. Berdasarkan rumusan pada Tabel 2, komponen yang akan dikendalikan seperti di bawah ini : Komponen mutlak (absolute):

1) Lokasi tapak

2) Luas tapak

3) Aksesibilitas

4) Standar luas fungsi utama

Komponen bersyarat (negotiable):

1) Zonasi penataan dalam tapak

2) Sirkulasi

3) Penanda / Rambu (signage)

4) Utilitas (penerangan \& pengairan)
Dalam proses perencanaan atau perizinannya, tidak seluruh kriteria dapat dipenuhi secara penuh oleh pengembang, oleh karena itu perlu ditentukan determinasi komponen dalam proses evaluasinya. Tingkat determinasi dibagi dua yaitu komponen mutlak dan komponen bersyarat. Komponen mutlak (absolute) adalah komponen yang wajib dipenuhi saat permohonan awal, mengacu persyaratan yang telah ditetapkan. Komponen ini bersifat critical karena terkait/berdampak langsung terhadap seluruh prinsip perencanaan rest-area (safety, security, convenience). Komponen mutlak dalam rest-area adalah: a) lokasi; b) luas tapak; c) aksesibilitas; d) standar luas fungsi utama.

Komponen bersyarat (negotiable) adalah komponen yang wajib dipenuhi namun diizinkan melalui penyesuaian bertahap atau perbaikan saat proses selanjutnya untuk memenuhi syarat yang ditetapkan. Komponen bersyarat rest-area dirumuskan yaitu a) zonasi, b) sirkulasi, c) penanda, dan d) utilitas. Komponen bersyarat ini terkait dengan tuntutan kualitas dan kelayakan pelayanan rest-area yang memiliki dampak langsung pada prinsip kenyamanan.

Tabel 3. Prinsip Perencanaan, Komponen dan Kriteria Pengendalian Rest-area pada Jalan Tol di Indonesia

\begin{tabular}{|c|c|c|c|}
\hline Sifat & $\begin{array}{c}\text { Komponen } \\
\text { Pengendalian }\end{array}$ & Kriteria Pengendalian & $\begin{array}{c}\text { Prinsip } \\
\text { Perencanaan }\end{array}$ \\
\hline \multirow{3}{*}{$\begin{array}{c}\text { Mutlak } \\
\text { (Absolute) }\end{array}$} & \multirow{3}{*}{ Lokasi Tapak } & $\begin{array}{l}\text { Berdasarkan panjang jalan tol dan tingkat kelelahan: } \\
\text { - } \quad \text { Panjang jalan tol tidak kurang dari } 30 \text { kilometer. } \\
\text { - } \quad \text { Jarak rest-area ke kota terdekat tidak kurang dari } 30 \\
\text { kilometer. } \\
\text { - Paling sedikit terdapat } 1 \text { (satu) rest-area dalam jarak } \\
\quad 50 \text { kilometer untuk Tipe A, dan } 30 \text { km untuk Tipe B. }\end{array}$ & Keselamatan \\
\hline & & $\begin{array}{l}\text { Berdasarkan interval jarak antar rest-area; } \\
\text { - Interval antara Tipe A dan Tipe B tidak kurang dari } 10 \\
\text { kilometer, kecuali berada pada jalur yang berbeda. } \\
\text { - Interval antar Tipe A tidak kurang dari } 20 \text { kilometer, } \\
\text { paling sedikit } 1 \text { (satu) rest-area Tipe A dalam } 50 \\
\text { kilometer, kecuali berada pada jalur yang berbeda. } \\
\text { - Interval antar Tipe B tidak kurang dari } 10 \text { kilometer, } \\
\text { paling sedikit } 1 \text { (satu) rest-area Tipe B dalam } 30 \\
\text { kilometer, kecuali berada pada jalur yang berbeda. } \\
\end{array}$ & Keselamatan \\
\hline & & $\begin{array}{l}\text { Berdasarkan kondisi bentang alam: } \\
\text { - } \quad \text { Terletak di luar daerah manfaat jalan. } \\
\text { - } \quad \text { Uji kestabilan lereng dan kelayakan struktur tanah. } \\
\text { - } \quad \text { Kemiringan lahan kurang dari } 20^{\circ} \text { dihitung dari level } \\
\text { terendah dan level tertinggi diperbandingkan dengan } \\
\text { panjang lahan yang menghadap jalan. } \\
\end{array}$ & $\begin{array}{c}\text { Keselamatan } \\
\text { Keamanan } \\
\text { Kenyamanan }\end{array}$ \\
\hline
\end{tabular}




\begin{tabular}{|c|c|c|c|}
\hline Sifat & $\begin{array}{c}\text { Komponen } \\
\text { Pengendalian }\end{array}$ & Kriteria Pengendalian & $\begin{array}{c}\text { Prinsip } \\
\text { Perencanaan } \\
\end{array}$ \\
\hline & & $\begin{array}{l}\text { - Terdapat sumber air bersih dan utilitas listrik dalam } \\
\text { radius kurang dari } 5 \text { kilometer. } \\
\text { - Lokasi tapak bukan area konservasi dan tidak terdapat } \\
\text { benda peninggalan sejarah yang bernilai historis. } \\
\text { - Lokasi bukan merupakan habitat hewan / tumbuhan } \\
\text { dilindungi (cagar alam) }\end{array}$ & \\
\hline & Luas Tapak & $\begin{array}{l}\text { Luas min. Tipe A adalah } 6 \text { Hektar, lebar min. } 150 \text { meter } \\
\text { Luas min. Tipe B adalah } 3 \text { Hektar, lebar min. } 100 \text { meter }\end{array}$ & $\begin{array}{l}\text { Keselamatan } \\
\text { Kenyamanan }\end{array}$ \\
\hline & Aksesibilitas & $\begin{array}{l}\text { - Terdapat jalur perlambatan pada jalur masuk dan } \\
\text { keluar dengan panjang minimal } 60 \text { meter terhadap } \\
\text { fasilitas umum (SPBU, area parkir, RTH, dll). } \\
\text { - } \text { Hanya terdapat satu akses masuk dan juga satu akses } \\
\text { keluar kendaraan keluar/masuk jalan tol. } \\
\text { - } \text { Lebar jalur perlambatan paling sedikit } 4 \text { meter/jalur }\end{array}$ & $\begin{array}{l}\text { Keselamatan } \\
\text { Keamanan } \\
\text { Kenyamanan }\end{array}$ \\
\hline & $\begin{array}{l}\text { Luas Fungsi/ } \\
\text { Fasilitas Utama }\end{array}$ & $\begin{array}{l}\text { - Tipe A, fasilitas minimalnya: ATM; toilet; bengkel; } \\
\text { klinik kesehatan; warung/kios; minimarket; mushola; } \\
\text { SPBU; restoran; RTH, playground; dan area parkir. } \\
\text { - Tipe B, fasilitas minimalnya: ATM; toilet; warung/ } \\
\text { kios; minimarket; mushola restoran; RTH; dan parkir } \\
\text { - } \quad \text { Luas lantai bangunan setiap fungsi utama mengacu } \\
\text { pada standar luas pada Tabel 1. }\end{array}$ & $\begin{array}{l}\text { Keselamatan } \\
\text { Kenyamanan }\end{array}$ \\
\hline Sifat & $\begin{array}{c}\text { Komponen } \\
\text { Pengendalian } \\
\end{array}$ & Kriteria Pengendalian & $\begin{array}{c}\text { Prinsip } \\
\text { Perencanaan }\end{array}$ \\
\hline \multirow{4}{*}{$\begin{array}{l}\text { Ber- } \\
\text { syarat } \\
(\text { Nego- } \\
\text { tiable })\end{array}$} & & $\begin{array}{l}\text { Berdasarkan Sempadan Bangunan (GSB) dan Koefisien } \\
\text { Dasar Bangunan (KDB): } \\
\text { - } \text { GSB tipe A paling sedikit } 20 \text { meter dihitung dari tepi } \\
\text { perkerasan jalan tol / berdasarkan lebar tol } \\
\text { - } \text { GSB tipe B paling sedikit } 15 \text { meter dihitung dari tepi } \\
\text { perkerasan jalan tol / berdasarkan lebar tol } \\
\text { - } \text { KDB tidak lebih dari } 40 \% \text { dari luas lahan }\end{array}$ & $\begin{array}{l}\text { Keselamatan } \\
\text { Kenyamanan }\end{array}$ \\
\hline & Zonasi Tapak & $\begin{array}{l}\text { Berdasarkan letak dan penataan fungsi; } \\
\text { - } \text { Orientasi bangunan memusat untuk meningkatkan } \\
\text { pengawasan mandiri (self-surveillance). } \\
\text { - } \text { Tata letak bangunan berdasarkan pengelompokan } \\
\text { fungsi, dan jenis kegiatannya. } \\
\text { - Kelompok fungsi perbaikan dan pemeliharaan } \\
\text { kendaraan (contoh: SPBU, bengkel, cuci mobil, dll) } \\
\text { dikelompokkan dalam zona terpisah, dengan jarak } \\
\text { aman atau pemisah dari kelompok fungsi peristirahatan } \\
\text { dan fungsi makan/minum } \\
\text { - Kelompok fungsi perbaikan dan perawatan kendaraan } \\
\text { diletakan terdekat dengan jalan tol. } \\
\text { - Kelompok fungsi peristirahatan diletakan pada zona } \\
\text { terjauh dari jalan tol. } \\
\text { - Pemisahan zona parkir kendaraan berat dan zona } \\
\text { kendaraan ringan, berdasarkan jenis golongannya. }\end{array}$ & $\begin{array}{l}\text { Keselamatan } \\
\text { Keamanan } \\
\text { Kenyamanan }\end{array}$ \\
\hline & \multirow[t]{2}{*}{ Sirkulasi } & $\begin{array}{l}\text { Berdasarkan sirkulasi kendaraan; } \\
\text { - Pemisahan lajur antara kendaraan berat dan ringan di } \\
\text { dalam kawasan dan pemisahan area parkirnya. } \\
\text { - Jalur kendaraan diberi pembedaan tekstur sebagai } \\
\text { media pengelolaan kecepatan kendaraan (traffic } \\
\text { calming) } \\
\text { - Terdapat jalur sirkulasi untuk memutari/ mengelilingi } \\
\text { rest-area di dalam tapak untuk Damkar. }\end{array}$ & $\begin{array}{l}\text { Keselamatan } \\
\text { Kenyamanan }\end{array}$ \\
\hline & & $\begin{array}{l}\text { Berdasarkan sirkulasi pejalan kaki: } \\
\text { - Tersedia jalur pejalan kaki yang tersambung dan } \\
\text { menghubungkan fungsi-fungsi di dalam rest-area }\end{array}$ & $\begin{array}{l}\text { Keselamatan } \\
\text { Keamanan } \\
\text { Kenyamanan }\end{array}$ \\
\hline
\end{tabular}




\begin{tabular}{|c|c|c|c|}
\hline Sifat & $\begin{array}{c}\text { Komponen } \\
\text { Pengendalian }\end{array}$ & Kriteria Pengendalian & $\begin{array}{c}\text { Prinsip } \\
\text { Perencanaan }\end{array}$ \\
\hline & & $\begin{array}{l}\text { - Dimensi lebar minimum jalur pejalan adalah } 120 \mathrm{~cm} \\
\text { (jalur searah) dan } 160 \mathrm{~cm} \text { (dua arah). } \\
\text { - Pengolahan elemen pembatas dan pengaman pejalan } \\
\text { kaki dari kendaraan (seperti bollards), elemen } \\
\text { peneduh, dan penerangan, dan traffic calming. }\end{array}$ & \\
\hline & \multirow[t]{2}{*}{$\begin{array}{l}\text { Penanda / } \\
\text { Rambu } \\
\text { (Signage) }\end{array}$} & $\begin{array}{l}\text { Penanda di luar tapak: } \\
\text { - Semua penanda/rambu dapat berfungsi baik pada siang } \\
\text { dan malam hari, dengan wujud dan latar belakang yang } \\
\text { tidak menyilaukan (anti-glare). } \\
\text { - } \text { Terdapat guidepost/reflector, pagar rumija, marka. } \\
\text { - } \text { Terdapat penanda aba-aba "Kelelahan Berakibat Fatal" } \\
\text { pada jarak satu kilometer sebelum lokasi. } \\
\text { - Terdapat penanda untuk melakukan perlambatan, } \\
\text { lokasi rest-area } 400 \text { meter sebelum lokasi. } \\
\text { - Terdapat penanda petunjuk masuk jalur lambat dan } \\
\text { informasi jarak rest-area berikutnya di gerbang keluar. } \\
\text { - Proporsi karakter penanda harus mempunyai rasio yang } \\
\text { mudah dibaca dalam kecepatan tinggi }\end{array}$ & $\begin{array}{l}\text { Keselamatan } \\
\text { Keamanan } \\
\text { Kenyamanan }\end{array}$ \\
\hline & & $\begin{array}{l}\text { Signage di dalam tapak: } \\
\text { - Terdapat penanda pengarah jalur sirkulasi dan } \\
\text { informasi letak jenis fasilitas di dalam lokasi }\end{array}$ & $\begin{array}{l}\text { Keselamatan } \\
\text { Keamanan } \\
\text { Kenyamanan }\end{array}$ \\
\hline & Utilitas & $\begin{array}{l}\text { - Terdapat sistem pencahayaan dengan tenaga cadangan } \\
\text { pada jalur sirkulasi dan penanda/rambu. } \\
\text { - Terdapat sistem pengairan utama dan cadangan } \\
\text { (PDAM \& sumur bor). Sistem pengolahan air limbah } \\
\text { tidak mengganggu pelayanan jalan tol. }\end{array}$ & $\begin{array}{l}\text { Keselamatan } \\
\text { Keamanan } \\
\text { Kenyamanan }\end{array}$ \\
\hline
\end{tabular}

Sejak dimulainya proses perencanaan, penting memastikan bahwa komponen mutlak dan seluruh kriterianya telah terpenuhi. Komponen bersyarat dan kriterianya dapat dipenuhi kemudian pada saat proses perancangan dilakukan. Kriteria pengendalian ini juga dapat dipergunakan sebagai instrumen evaluasi kelayakan perencanaan rest-area yang telah beroperasi pada jalan tol. Kriteria pengendalian rest-area pada jalan tol di Indonesia dapat dilihat pada Tabel 3.

\section{KESIMPULAN DAN REKOMENDASI}

Prinsip perencanaan rest-area
dirumuskan untuk memastikan hasil perencanaan rest-area dapat mengurangi bahkan meniadakan dampak gangguan pembangunannya yang akan terjadi di masa akan datang. Prinsip perencanaan rest-area pada jalan tol di Indonesia yaitu wajib memenuhi prinsip keselamatan, keamanan, dan kenyamanan bagi pelanggan dan pengendara jalan tol di sekitar rest-area. Komponen dan kriteria pengendalian rest-area dapat diklasifikasikan dalam komponen mutlak dan bersyarat, yaitu dua kelompok komponen dengan determinasi yang berbeda. Komponen dan kriteria pengendalian ini juga dapat dipergunakan untuk mengevaluasi kelayakan dan tingkat pelayanan rest-area yang sudah beroperasi (evaluasi laik fungsi).

\section{DAFTAR PUSTAKA}

Al-Kaisy, A., Veneziano, D., Kirkemo, Z., \& Dorrington, C. (2012). Practical Guidelines for Estimation of Rest Area Use on Rural Interstates and Arterial Highways. Journal of Transportation Research Record, 2303 (1), 117-124. https://doi.org/10.3141/2303-13

Arini, S. Y., \& Dwiyanti, E. (2017). Analisis Faktor Yang Berhubungan Dengan Terjadinya Kelelahan Kerja Pada Pengumpul Tol Di Perusahaan Pengembang Jalan Tol Surabaya. The Indonesian Journal of Occupational Safety and Health, 4 (2), 113. https://doi.org/ 10.20473/ijosh.v4i2.2015.113-122 
Arvidsson, A. (2007). Creative Class or Administrative Class?: On Advertising and the "Underground." Ephemera, Theory and Politics in Organization, 7 (1), 8-23. http://www.ephemeraweb.org/journal/7-1/71arvidsson.pdf

Autoceste, H. (2012). Traffic Safety on the A2 Motorway. Newsletter 24: The Croatian Association of Toll Motorways Concessionaries. HUKA. Zagreb. ISSN: 1848-0675.

CNN Indonesia. (2019). Bikin Macet Saat Mudik, PUPR Evaluasi Desain Rest-Area Tol. Konferensi Pers Kementerian Pekerjaan Umum dan Perumahan Rakyat (PUPR). https://www.cnnindonesia.com/ekonomi/2019 0612112623-92-402620/bikin-macet-saatmudik-pupr-evaluasi-desain-rest-area-tol. [12 Juni 2019]

Cuesta, R., Sarris, C., Signoretta, P., \& Moughtin, J. C. (2003). Urban Design: Method and Techniques (2nd Edition). Routledge. https://doi.org/https://doi.org/10.4324/978008 0520254

Dumbaugh, E., \& Gattis, J. L. (2005). Safe Streets, Livable Streets. Journal of the American Planning Association, 71 (3), 283-300. https://doi.org/10.1080/01944360508976699

Elfiansyah, T. I. (2007). Fasilitas Rest-area Tipe A pada Ruas Jalan Tol Cipularang. Tugas Akhir. Jurusan Arsitektur Fakultas Teknik Universitas Diponegoro. Semarang.

Hanafi, Rusgiyarto, F., Pratama, R., \& Hatta, M. R. (2020). Analisis Tingkat Keselamatan Jalan Tol Berdasarkan Metode Pembobotan Korlantas (Studi Kasus: Jalan Tol Cipularang). Jurnal Teknik: Media Pengembangan Ilmu Dan Aplikasi Teknik, 18 (2), 49. https://doi.org/10.26874/jt.vol18no 2.106

Hartopo, R. (2006). Kajian Tingkat Pelayanan Restarea Jalan Tol Menurut Persepsi Pengguna. Tugas Akhir. Jurusan Perencanaan Wilayah Dan Kota Fakultas Teknik Universitas Diponegoro. Semarang.

Harvey, C., \& Aultman-Hall, L. (2015). Urban Streetscape Design and Crash Severity. Transportation Research Record, 2500 (1), 18. https://doi.org/10.3141/2500-01
Karsaman, R. H. (2010). Audit Keselamatan Jalan Tol di Indonesia (Studi Kasus Jalan Tol Cikampek - Padalarang/Cipularang). Jurnal Teknik Sipil ITB, 14 (3), 135-142. https://doi.org/10.5614/jts.2007.14.3.2

Kementerian, P. U. P. R. (2018). Peraturan Menteri PUPR No. 10/PRT/M/2018 tentang Tempat Istirahat dan Pelayanan Jalan Tol. Jakarta.

Laskara, G. W. (2016). Strategi Implementasi Compact City Menuju Pengembangan Kawasan Perkotaan Berkelanjutan. Prosiding Seminar Konsepsi \#2 Infrastruktur-Bangunan -Konstruksi: Berbasis Lingkungan Kepariwisataan Berkearifan Lokal. Warmadewa University Press. ISBN 978-6021582-12-1. Denpasar.

Laskara, G. W., Dwijendra, N. K. A., Pebriyanti, N. L. P. E., \& Jaya, P. M. D. (2020). Planning Principles of Permanent Outdoor Advertising (POA) in Arterial and Collector Road Corridors in Denpasar City, Bali, Indonesia. Journal of Social and Political Sciences, Asian Institute of Research., 3 (4), 968-982. https://doi.org/10.31014/aior.1991.03.04.229

Magfirona, A., Hidayati, N., \& Sunarjono, S. (2018). Review of traffic safety management on toll road. Human-Dedicated Sustainable Product and Process Design: Materials, Resources, and Energy: AIP Conference Proceedings 1977. https://doi.org/10.1063/1.5042992

Makmur, A., \& Rajagukguk, R. P. (2015). Evaluasi Pemenuhan Indikator Standar Pelayanan Minimal Jalan Tol di Indonesia. Jurnal Transportasi, 15 (2), 107-114.

Marga, B. D. J. (1999). Tata Cara Penentuan Lokasi Tempat Istirahat di Jalan Bebas Hambatan Direktorat Jenderal Bina Marga. PT. Mediatama Saptakarya.

Marga, J. P. T. (2015). Paparan Publik Jasa Marga Indonesian Highway Corp. Investor Summit and Capital Market Expo 2015.11. https://cms.jasamarga.com/id/hubunganinvest or/Paparan\%20Publik/Materi\%20Public\%20E xpose\%20[JSMR].pdf.[11 November 2015] 
Marga, J. P. T. (2019). Jasa Marga Catat Rekor Layani Volume Lalu Lintas Tertinggi di Sepanjang Sejarah Jalan Tol di Indonesia. Jasa Marga Press Release Nomor:122/2019, https://www.jasamarga.com/public/id/aktivita s/detail.aspx?title=Jasa \%20Marga \%20Catat $\%$ 20Rekor\%20Layani\%20Volume\%20Lalu\%2 0Lintas\%20Tertinggi\%20di\%20Sepanjang\% 20Sejarah\%20Jalan\%20Tol\%20di\%20Indone sia. [10 Juni 2019]

Moughtin, C. (2003). Urban Design: Street and Square (3rd ed.). Routledge. https://doi.org/10.4324/9780080520278

Ogden, K. W., Bennet D. W. (1984). Traffic Engineering Practice. Department of Civil Engineering, Monash University.

Patton, M. Q. (1987). How to Use Qualitative Methods in Evaluation (Issue 4). SAGE.

Pérez-Acebo, H., \& Romo-Martín, A. (2019). Service and rest areas in toll motorways in Poland: Study of distribution and facilities. Journal of Transport Problems, 14 (2), 155-164. https://doi.org/10.20858/tp.2019.14.2.14

Perhubungan, K. D. J. P. D. (2019). Kemenhub Bentuk Tim Kurangi Kecelakaan di Jalan Tol. Konferensi Pers Direktorat Jenderal Perhubungan Darat, Kementerian Perhubungan. https://ekonomi.bisnis.com/read/20190309/98 /897649/kemenhub-bentuk-tim-kurangikecelakaan-di-jalan-tol. [9 Maret 2019]

Pickett, S. T. A., Cadenasso, M. L., \& McGrath, B. (2013). Resilience in Ecology and Urban Design: Linking Theory and Practice for Sustainable Cities. Springer.

Pratama, A. F. (2014). Rest Area Jadi Penyebab Kemacetan di Cipularang. Ed. Wardhani, AK. https://www.tribunnews.com/nasional/2014/0 8/04/rest-area-jadi-penyebab-kemacetan-dicipularang. [4 Agustus 2014]

Purboyo, H., \& Santoso, E. B. (2016). The Growth of Rest Area at the Development Axis in the Southern Part of West Java. Journal Procedia - Social and Behavioral Sciences, 227, 637641. https://doi.org/10.1016/j.sbspro.2016.06. 126

Russel, V. (1986). Otto Klepprer's Advertising Procedure. SAGE 